\title{
ANALISIS PELAYANAN PRIMA ATAS KEPUASAN KONSUMEN PADA APOTEK K24 BAMBU APUS JAKARTA TIMUR
}

\author{
Dahlia Sarkawi, Anggi Oktaviani, Agus Priadi, Thany Khansa \\ ASM BSI Jakarta, STMIK Nusa Mandiri Jakarta,ABA BSI Jakarta,ASM BSI Jakarta \\ Email: dahlia.dls@bsi.ac.id, anggi.aov@nusamandiri.ac.id, agus.agp@bsi.ac.id
}

\begin{abstract}
ABSTRAK
Pelayanan prima bukanlah istilah baru dalam dunia kerja. Perusahaan harus mampu memberikan pelayanan terbaik kepada konsumen sehingga dapat memberikan kepuasan kepada konsumen. Kepuasan konsumen dijadikan sebagai kunci utama dalam mempertahankan eksistensi dari suatu perusahaan. Penelitian bertujuan untuk mengetahui pengaruh pelayanan prima terhadap kepuasan konsumen. Penelitian ini menggunakan metode kuantitatif dengan 90 sampel penelitian dengan teknik penarikan sampel non probability, khususnya purposive sampling. Berdasarkan analisis data, hasil penelitian pada koefisien korelasi menunjukkan bahwa 0,183 yang menunjukkan bahwa terdapat hubungan yang sangat lemah antara pelayanan prima terhadap kepuasan konsumen. Dari uji koefisien determinasi diperoleh hasil pengaruh variabel pelayanan prima terhadap variabel kepuasan konsumen sebesar 3,4\% dan sisanya 96,6\% dipengaruhi oleh variabel-variabel lain yang tidak diteliti oleh penulis. Hasil regresi sederhana diperoleh $Y=$ $27,072+0,168 X$ yang menghasilkan jika pelayanan prima dianggap konstan maka kepuasan konsumen akan positif dan signifikan. Dan hasil uji $T$, pelayanan prima berpengaruh terhadap kepuasan konsumen dengan $t$ hitung $>$ t tabel $=1,750>1,662$, maka $H_{a}$ diterima.
\end{abstract}

Kata Kunci: pelayanan, prima, kepuasan, konsumen, apotek

\begin{abstract}
Excellent service isn't a new term in the world of work. The company must be able to give the best service to consumers so as to give satisfaction to consumers. Consumer satisfaction serve as the main key in maintaining the existence of a company. The research aims to determine the influence of excellent service to consumer satisfaction. This research use quantitative method. This research use quantitative method with 90 samples research with nonprobability sampling technique, especially purposive method. Based on data analysis, the result of research on the correlation coefficient show that 0.183 indicating that there is a very weak relationship between excellent service to consumer satisfaction. From the determination coefficient test obtained the influence of service excellent variable on cosumer satisfaction variable is $3.4 \%$ and the remaining $96.6 \%$ influenced by other variables not examined by the author. The result of simple regression obtained $Y=27,072+0,168 X$ which result if excellent service is considered constant then consumer satisfaction will be positive and significant. And T test results, excellent service influence on customer satisfaction with t count $>$ t table $=1.750>1.662$, then Ha accepted.
\end{abstract}

Keywords: service, prime, satisfaction, consumer, pharmacy 


\section{PENDAHULUAN}

Kelangsungan hidup dari suatu usaha sangat ditentukan atau tergantung dari persepsi konsumen terhadap perusahaan tersebut. Setiap perusahaan tentunya ingin mendapat tempat yang baik di hati konsumen. Berbagai cara pun ditempuh oleh perusahaan untuk mendapatkan tempat di hati konsumen. Adanya usaha yang sama membuat perusahaan harus mampu memberikan pelayanan terbaik kepada konsumen sehingga dapat memberikan kepuasan kepada konsumen. Selama ini, kepuasan konsumen dijadikan sebagai kunci utama dalam mempertahankan eksistensi dari suatu perusahaan.

Suatu pelayanan juga harus dihubungkan dengan harapan dan keinginan konsumen terhadap produk atau jasa yang ditawarkan perusahaan agar konsumen merasa puas. Jadi unit pelayanan perusahaan seharusnya memiliki kemampuan untuk mengetahui apa yang menjadi keinginan konsumen, sehingga dapat menjadi masukan bagi perusahaan untuk memperbaiki kualitas produk atau jasa yang dihasilkan karena konsumen yang berhak untuk menilai kualitas suatu produk atau jasa dengan membandingkan yang mereka harapkan dengan yang mereka terima.

Salah satu cara yang dilakukan oleh banyak perusahaan belakangan ini dalam mewujudkan kepuasan konsumen dengan memberikan pelayanan yang optimal atau disebut juga dengan pelayanan prima. Pelayanan prima bukanlah istilah baru dalam dunia kerja. Pelayanan prima harus ditunjang oleh kualitas sumber daya manusia yang handal, mempunyai visi yang jauh ke depan dan dapat mengembangkan strategi dan kiat pelayanan prima yang mempunyai keunggulan. Di samping itu, harus diupayakan terus menerus untuk meningkatkan kemampuan para petugas pelayanan agar dapat menumbuhkan dedikasi dan memberikan pelayanan sebaik-baiknya kepada konsumen untuk tetap setia menggunakan produk atau jasa kita tanpa sempat lagi melirik atau memakai produk lain.

Apotek merupakan unit pelayanan kesehatan masyarakat, selain itu apotek juga menyediakan obat-obat yang dibutuhkan oleh masyarakat. Berkaitan dengan bisnis, sudah selayaknya apotek menjadikan kepuasan sebagai prioritas utama. Kepuasan yang dirasakan konsumen dapat diperoleh dari pelayanan prima yang diberikan apotek tersebut.

Apotek adalah industri yang mengalami pertumbuhan di Indonesia. Usaha yang berbentuk waralaba ini sekarang dapat di jumpai di berbagai tempat. Salah satunya Apotek K24 Bambu Apus Jakarta Timur yang merupakan usaha apotek waralaba yang menyediakan kebutuhan obat-obatan, baik obat bebas maupun obat resep, dan alat kesehatan. Apotek K24 selalu berusaha memberikan pelayanan yang terbaik bagi masyarakat umum. Memberikan pelayanan yang terbaik adalah hal yang terpenting bagi suatu perusahaan agar konsumen dapat merasakan kepuasan dan terciptanya hubungan baik antara perusahaan dengan konsumen.

Berdasarkan latar belakang masalah yang telah dikemukakan, maka yang menjadi masalah dalam penelitian ini dapat dirumuskan melalui hipotesis sebagai berikut:

$\mathrm{H}_{\mathrm{o}}$ : Tidak terdapat pengaruh antara pelayanan prima terhadap kepuasan konsumen.

$\mathrm{H}_{1}$ : Terdapat pengaruh antara pelayanan prima terhadap kepuasan konsumen.

\section{LANDASAN TEORI}

\section{Pelayanan Prima}

Pelayanan prima bukanlah istilah baru dalam dunia kerja, baik yang bersifat profit maupun non profit. Bentuk pelayanan prima diantaranya ramah, senyum, sopan, cepat, tepat, terbuka dan tanggung jawab. Semua tidak terlepas terhadap tiga komponen penting yaitu adanya attituade, skill dan knowledge yang berakhir pada kompetensi yang handal sebagai aparatur pemerintah.

Pelayanan prima merupakan terjemahan istilah "excellent service" yang secara harfiah berarti pelayanan terbaik atau sangat baik. Disebut sangat baik atau terbaik karena sesuai dengan standar pelayanan yang berlaku atau dimiliki instansi pemberi pelayanan.

Secara etimologis, "pelayanan ialah usaha melayani kebutuhan orang lain". (Daryanto \& Setyobudi, 2014). Pelayanan pada dasarnya adalah kegiatan yang ditawarkan kepada konsumen yang dilayani, yang bersifat tidak berwujud dan tidak dapat dimiliki. 


\section{JURNAL PETIR}

Vol. 11, No. 2, September 2018, P-ISSN 1978-9262, E-ISSN 2655-5018

Sejalan dengan hal tersebut, menurut Norman bahwa karakteristik pelayanan sebagai berikut: (Daryanto \& Setyobudi, 2014)

1. Pelayanan bersifat tidak dapat diraba, pelayanan sangat berlawanan sifatnya dengan barang jadi.

2. Pelayanan pada kenyataannya terdiri dari tindakan nyata dan merupakan pengaruh yang bersifat tindakan sosial.

3. Kegiatan produksi dan konsumsi dalam pelayanan tidak dapat dipisahkan secara nyata, karena pada umumnya terjadi dalam waktu dan tempat bersamaan.

Pengertian lebih luas disampaikan Daviddow dan Uttal bahwa "pelayanan merupakan usaha apa saja yang mempertinggi kepuasan konsumen". (Daryanto \& Setyobudi, 2014). Pelayanan prima adalah kegiatan untuk memberikan nilai tambah agar dapat memenuhi atau melampaui harapan konsumen. Pelayanan prima merupakan terjemahan dari "Excellent Service", yang berarti pelayanan yang sangat baik atau pelayanan yang terbaik.

Lehtinen mengemukakan bahwa "pelayanan adalah suatu kegiatan atau suatu urutan kegiatan yang terjadi dalam interaksi langsung dengan manusia atau mesin secara fisik untuk menyediakan kepuasaan konsumen." (Daryanto \& Setyobudi, 2014)

Pelayanan dalam bahasa inggris disebut service. Beberapa pakar tentang pelayanan prima mengolah kata service yang lebih bermakna. Untuk melaksanakan tugas sebagai abdi negara atau abdi masyarakat tentunya didasar pada pelayanan yang mengacu pada kepuasaan konsumen/masyarakat (customer satisfaction) yang dilayani.

\section{Kepuasan Konsumen}

Menurut Schanaanrs dalam Sunyoto menyatakan bahwa: (Sunyoto, 2014). Pada dasarnya tujuan dari suatu bisnis adalah untuk menciptakan para konsumen yang merasa puas, karena terciptanya kepuasan konsumen dapat memberikan beberapa manfaat, diantaranya hubungan perusahaan dan konsumennya menjadi harmonis, memberikan dasar yang baik bagi pembelian ulang dan terciptanya loyalitas konsumen dan membentuk suatu rekomendasi dari mulut ke mulut (word of mouth) yang menggantungkan bagi perusahaan.

Menurut Juran dalam Daryanto \& Setyobudi menyatakan bahwa, "kepuasan konsumen adalah keadaan yang dicapai bila produk sesuai dengan kebutuhan atau harapan konsumen dan bebas dari kekurangan". Kepuasan konsumen dapat didefinisikan pula sebagai suatu keadaan dimana kebutuhan, keinginan dan harapan konsumen dapat terpenuhi melalui produk yang dikonsumsi. (Daryanto \& Setyobudi, 2014)

Menurut Roland T. Rust, "penyedia jasa harus memperhatikan apa yang konsumen persepsikan atas jasa yang diberikan, tetapi juga bagaimana mereka dapat merasakan kepuasan". (Daryanto \& Setyobudi, 2014)

Kedalaman dari perasaan ini merupakan hasil dari tingkat seberapa jauh persepsi dari konsumen dapat sesuai dengan apa yang mereka harapkan (kepuasan) harus diminimalisasi agar hasilnya mendekati atau lebih dari satu, yaitu dengan mengelola kesenjangan-kesenjangan yang terjadi pada penyerahan jasa. Penyedia harus memperbaiki kualitas jasa setiap saat dan semakin agresif untuk mengadakan penilitian akan kepuasan dan ketidakpuasan konsumen.

Menurut Brown, "kepuasan konsumen adalah kondisi terpenuhinya kebutuhan, keinginan, dan harapan konsumen terhadap sebuah produk dan jasa". (Yuniarti, 2015)

Sedangkan Wells menyatakan bahwa, "kepuasan konsumen merupakan sikap konsumen terhadap suatu produk dan jasa sebagai hasil dari evaluasi konsumen berdasarkan pengalaman konsumen setelah menggunakan sebuah produk dan jasa". (Yuniarti, 2015)

\section{Metode Pengukuran Kepuasan Konsumen}

Kepuasan konsumen dapat diukur dengan berbagai metode dan teknik. Menurut Kotler, bahwa metode dalam pengukuran kepuasan konsumen adalah berikut ini: (Windasuri \& Susanti, 2017)

1. Sistem Keluhan dan saran

Setiap perusahaan yang berfokus pada konsumen mempermudah konsumen untuk memberikan saran dan keluhan terhadap perusahaan. Setiap organisasi yang berorientasi pada 
konsumen perlu memberikan kesempatan yang luas kepada para konsumennya untuk menyampaikan saran, pendapat, dan keluhan.

2. Ghost Shopping atau mystery shopper

Salah satu cara untuk memperoleh gambaran mengenai kepuasan konsumen adalah dengan mempekerjakan beberapa orang untuk berperan atau bersikap sebagai konsumen potensial produk perusahaan dan pesaing. Kemudian mereka melaporkan temuan-temuannya mengenai kekuatan dan kelemahan produk pesaing berdasarkan pengalaman tersebut.

3. Analisis Konsumen yang Hilang

Perusahaan harus menghubungi para pelanggan yang telah berhenti membeli produk perusahaan ataupun telah berpindah ke pemasok lain untuk mempelajari penyebabnya.

4. Survei Kepuasan Konsumen

Perusahaan harus menghubungi para pelanggan yang telah berhenti membeli produk perusahaan ataupun telah berpindah ke pemasok lain guna mempelajari alasannya. Ada dua hal yang harus diperhatikan. Pertama, mewawancara konsumen yang berhenti membeli melaui survei perusahaan akan memperoleh tanggap baik (feed back) secara langsung dari konsumen dan juga memberikan tanda (sugnal) positif bahwa perusahaan memberikan perhatian khusus terhadap para konsumennya. Kedua, adalah memantau tingkat kehilangan konsumen.

\section{Tipe-tipe Kepuasan Konsumen}

Menurut Price Arnould dan Zinkhan dalam Yuniarti menyatakan bahwa tipe-tipe kepuasan konsumen terdiri atas sebagai berikut: (Yuniarti, 2015)

1. Kepuasan sebagai Contentment

Contentment merupakan respons yang pasif. Pada tipe ini, ketika ditanya seberapa puas mereka terhadap suatu produk atau jasa, konsumen tidak begitu memikirkannya atau tidak begitu terlibat didalamnya.

2. Kepuasan sebagai Pleasure

Pada tipe ini, konsumen terlibat secara aktif dalam proses penampilan barang atau jasa.

3. Kepuasan sebagai Delight

Kadang-kadang penampilan produk atau jasa menyebabkan timbulnya kesenangan dan kejutan yang disebut delight. Pada tipe ini, delight respons merupakan respons positif dari suatu kejadian atau hasil konsumen tidak mengharapkannya.

4. Kepuasan sebagai Ambivalence

Tipe ini, merupakan respons untuk menunjukkan, menolong konsumen menginterprestasikan harapan dan hasil serta mengatur asimilasi dan efek yang berlawanan menjadi hal yang penting.

\section{Ciri-ciri Kepuasan Konsumen}

Menurut Kotler bahwa konsumen merasa puas: (Yuniarti, 2015)

1. Loyal terhadap produk, yaitu membeli ulang dari produsen yang sama.

2. Adanya komunikasi dari mulut ke mulut yang bersifat positif, yaitu rekomendasi kepada calon konsumen lain dan mengatakan hal-hal yang baik mengenai produk dan perusahaan produk yang dikonsumsi.

3. Perusahaan menjadi pertimbangan utama, yaitu ketika membeli merek lain perusahaan yang telah memberikan kepuasan kepadanya akan menjadi pertimbangan utama.

\section{METODOLOGI PENELITIAN}

\section{Konsep Dasar Operasional dan Perhitungan}

Berikut adalah tabel operasional variabel yang terdiri dari variabel pelayanan prima dan variabel kepuasan konsumen yang berisi tentang dimensi dan indikator untuk dibuat daftar pernyataan kuesioner. Dalam penelitian ini peneliti menggunakan skala likert untuk kuesioner.

Menurut Prasetyo dan Jannah menyatakan bahwa: (Prasetyo \& Jannah, 2012) 
Skala likert berisi pernyataan yang sistematis untuk menunjukkan sikap seorang responden terhadap pernyataan itu. Indeks ini mengasumsikan bahwa masing-masing kategori jawaban ini memiliki intensitas yang sama. Keunggulan indeks ini adalah kategorinya memiliki urutan yang jelas mulai dari sangat setuju, setuju, ragu-ragu, tidak setuju dan sangat tidak setuju.

Tabel III.1. Operasional Variabel

\begin{tabular}{|c|c|c|c|c|}
\hline Variabel & Dimensi & Indikator & $\begin{array}{c}\text { Butir } \\
\text { Pernyataan }\end{array}$ & Sumber \\
\hline \multirow{3}{*}{$\begin{array}{c}\text { Pelayanan } \\
\text { Prima }\end{array}$} & $\begin{array}{c}\text { Attituade } \\
\text { (Sikap) }\end{array}$ & $\begin{array}{l}\text { 1. Pelayanan dengan berpikir } \\
\text { positif. } \\
\text { 2. Pelayanan memberikan } \\
\text { informasi. } \\
\text { 3. Pelayanan dengan } \\
\text { penampilan serasi. }\end{array}$ & $\begin{array}{l}\mathrm{P} 2 \\
\mathrm{P} 3\end{array}$ & \multirow{3}{*}{$\begin{array}{l}\text { Daryanto dan } \\
\text { Setyobudi, } \\
\text { Ismanto } \\
(2014: 119)\end{array}$} \\
\hline & $\begin{array}{l}\text { Attention } \\
\text { (Perhatian) }\end{array}$ & $\begin{array}{l}\text { 1. Mendengarkan dan } \\
\text { memahami kebutuhan } \\
\text { konsumen. } \\
\text { 2. Mencurahkan perhatian } \\
\text { kepada konsumen. } \\
\end{array}$ & $\begin{array}{l}\text { P4 } \\
\text { P5 } \\
\end{array}$ & \\
\hline & $\begin{array}{c}\text { Action } \\
\text { (Tindakan) }\end{array}$ & $\begin{array}{l}\text { 1. Mencatat kebutuhan } \\
\text { konsumen. } \\
\text { 2. Menegaskan kebutuhan } \\
\text { konsumen. } \\
\text { 3. Mengucapkan terima kasih } \\
\text { pada akhir pelayanan. }\end{array}$ & $\begin{array}{l}\text { P6 } \\
\text { P7 } \\
\text { P8 }\end{array}$ & \\
\hline \multirow{4}{*}{$\begin{array}{c}\text { Kepuasan } \\
\text { Konsumen }\end{array}$} & $\begin{array}{l}\text { Kualitas } \\
\text { Produk }\end{array}$ & $\begin{array}{l}\text { 1. Kualitas produk tidak cacat. } \\
\text { 2. Ketahanan produk (obat, } \\
\text { vitamin atau alat kesehatan). }\end{array}$ & $\begin{array}{l}\text { P9 } \\
\text { P10 }\end{array}$ & \multirow{4}{*}{$\begin{array}{c}\text { Lupiyoadi } \\
\text { dalam Yuniarti } \\
(2015: 239)\end{array}$} \\
\hline & Pelayanan & $\begin{array}{l}\text { 1. Pelayanan yang sigap dan } \\
\text { ramah. } \\
\text { 2. Mampu memberikan } \\
\text { informasi yang lengkap. }\end{array}$ & P11 & \\
\hline & Harga & $\begin{array}{l}\text { 1. Harga produk lebih murah. } \\
\text { 2. Potongan harga produk } \\
\text { (obat, vitamin atau alat } \\
\text { kesehatan) tertentu. }\end{array}$ & $\begin{array}{l}\text { P13 } \\
\text { P14 }\end{array}$ & \\
\hline & $\begin{array}{l}\text { Biaya dan } \\
\text { Kemudahan }\end{array}$ & $\begin{array}{l}\text { 1. Lokasi dapat dijangkau } \\
\text { dengan mudah. } \\
\text { 2. Pelayanan dikasir dan } \\
\text { meracik resep obat tidak } \\
\text { perlu menunggu lama. }\end{array}$ & $\begin{array}{l}\text { P15 } \\
\text { P16 }\end{array}$ & \\
\hline
\end{tabular}

\section{Uji Instrumen Penelitian}

\section{Uji Validitas}

Menurut Sujarweni menyatakan bahwa, "uji validitas digunakan untuk mengetahui kelayakan butir-butir dalam suatu daftar pertanyaan dalam mendefinisikan suatu variabel" (Sujarweni, 2015). Daftar pertanyaan ini pada umumnya mendukung suatu kelompok variabel tertentu. Uji validitas sebaiknya dilakukan pada setiap butir pertanyaan di uji validitasnya. Hasil $r$ hitung kita bandingkan dengan $\mathrm{r}$ tabel dimana $\mathrm{df}=\mathrm{n}-2$ dengan signifikansi 0,10 . Jika $\mathrm{r}$ tabel $<\mathrm{r}$ hitung maka valid. Uji 
validitas menggunakan teknik korelasi pearson product moment dengan menggunakan rumus sebagai berikut:

Dimana :

$$
r=\frac{n \sum x y-\left(\sum x\right)\left(\sum y\right)}{\sqrt{\left[n \sum x^{2}-\left(\sum x\right)^{2}\right]\left[n \sum y^{2}-\left(\sum y\right)^{2}\right]}}
$$

$\mathrm{n}=$ jumlah observasi/responden

$\mathrm{x}=$ skor total yang diperoleh dari seluruh item variabel $\mathrm{x}$

$\mathrm{y}=$ skor total yang diperoleh dari seluruh item variabel $\mathrm{y}$

\section{Uji Reliabilitas}

Menurut Sujarweni (2015:172) menyatakan bahwa, "reliabilitas merupakan ukuran suatu kestabilan dan konsistensi responden dalam menjawab hal yang berkaitan kontruk-kontruk pertanyaan yang merupakan dimensi suatu variabel dan disusun dalam suatu bentuk kuesioner". berikut:

Rumus yang digunakan untuk menguji reliabilitas yaitu rumus Cronbach's Alpha sebagai

$$
\begin{gathered}
r=\left[\frac{k}{k-1}\right]\left[1-\frac{\sum \sigma_{b^{2}}}{\sigma_{t^{2}}}\right] \\
\sigma^{2}=\frac{\sum x^{2}-\frac{\left(\sum x\right)^{2}}{n}}{n}
\end{gathered}
$$

Keterangan :

$\mathrm{k} \quad=$ Banyaknya butir pertanyaan

$\sum \sigma^{2}=$ Total butir pertanyaan

$\sigma_{\mathrm{t}^{2}}=$ Total Varian

$\mathrm{n}=$ Jumlah responden

Pengukuran reliabilitas dalam penelitian ini dibantu dengan SPSS untuk uji statistik Cronbach Aplha $(\alpha)$. Hasil dari uji statistik Cronbach Aplha $(\alpha)$ akan menentukan instrumen yang digunakan dalam penelitian ini reliabel digunakan atau tidak.

Apabila nilai reliabilitas sudah diketahui maka langkah selanjutnya adalah dengan mengkonsultasikan koefisien reliabilitas dengan tabel berikut ini:

Tabel III.2. Interpretasi Reliabilitas

\begin{tabular}{|c|c|}
\hline Rentang Nilai & Interprestasi Reliabilitas \\
\hline $0,80-1,00$ & Sangat Tinggi \\
\hline $0,60-0,80$ & Tinggi \\
\hline $0,40-0,60$ & Sedang \\
\hline $0,20-0,40$ & Rendah \\
\hline
\end{tabular}

Sumber : Setiawan, (2015:140)

\section{Konsep Dasar Perhitungan}

\section{Populasi dan Sampel}

Menurut Sujarweni menyatakan bahwa, "populasi adalah wilayah generalisasi yang terdiri atas obyek/subyek yang mempunyai kualitas dan karakteristik tertentu yang ditetapkan oleh peneliti untuk dipelajari dan kemudian ditarik kesimpulannya". (Sujarweni, 2015)

Menurut Sujarweni menyatakan bahwa "sampel adalah bagian dari jumlah dan karakteristik yang dimiliki oleh populasi. Bila populasi besar tidak mungkin mempelajari semua yang ada pada 
populasi. Apa yang dipelajari dari sampel, kesimpulannya akan dapat diberlakukan untuk populasi." (Sujarweni, 2015)

Teknik pengambilan sampel dalam penelitian ini adalah dengan menggunakan Non Probability Sampling. Menurut Prasetyo \& Jannah, "teknik penarikan sampel nonprobability dapat digunakan apabila peneliti tidak memiliki kerangka sample yang memadai" (Prasetyo \& Jannah, 2012). Pengambilan sampel diambil dengan menggunakan metode jenis purposive sampling. Menurut Prasetyo dan Jannah menyatakan bahwa, "teknik penarikan sampel purposive disebut juga judmental sampling yang digunakan dengan menentukan kriteria khusus terhadap sampel terutama orang-orang yang dianggap ahli" (Prasetyo \& Jannah, 2012). Karena didalam menentukan sampel ada pertimbangan kriteria tertentu, yaitu sampel harus konsumen apotek K24 di Bambu Apus, Jakarta Timur.

Rumus sampel yang digunakan dalam penelitian ini adalah metode slovin:

Dimana:

$$
n=\frac{N}{1+n e^{2}}
$$

$n=$ Jumlah sampel

$\mathrm{N}=$ Besaran populasi (dalam waktu satu bulan)

$\mathrm{e}=$ nilai kritis (batas ketelitian) yang diinginkan (persen kelonggaran ketidaktelitian karena kesalahan penarikan sampel). (Riadi, 2016)

\section{Uji Koefisien Korelasi}

Menurut Sunyoto mendefinisikan bahwa, "koefisien korelasi adalah suatu analisis yang digunakan untuk mengetahui kuat tidaknya hubungan yang terjadi antara variabel bebas dengan variabel terikat baik berganda maupun parsial”. (Sunyoto, 2014)

Menurut Riadi menyatakan bahwa, "korelasi pearson atau lazim disebut Korelasi Product Moment adalah alat uji statistik parametrik yang digunakan untuk menguji hubungan dua sampel acak, homogen dan berdistribusi normal" (Riadi, 2016). Adapun data yang digunakan harus berskala interval atau rasio. Nilai koefisien korelasi dapat dihitung dengan rumus berikut:

Keterangan :

$$
r=\frac{n \sum x y-\left(\sum x\right)\left(\sum y\right)}{\sqrt{\left[n \sum x^{2}-\left(\sum x\right)^{2}\right]\left[n \sum y^{2}-\left(\sum y\right)^{2}\right]}}
$$

$$
\begin{array}{ll}
\mathrm{r} & =\text { koefisien korelasi antara } \mathrm{x} \text { dan } \mathrm{y} \\
\mathrm{n} & =\text { Jumlah responden } \\
\Sigma \mathrm{xy} & =\text { Jumlah total data variabel } \mathrm{x} \\
\mathrm{y} & =\text { Jumlah total data variabel } \mathrm{y}
\end{array}
$$

Untuk memberi interpretasi atau menjelaskan seberapa kuat hubungan atau korelasinya, maka dapat digunakan pedoman sebagai berikut:

Tabel III.3. Interpretasi Koefisien Korelasi

\begin{tabular}{|c|c|}
\hline Interval Koefisien & Tingkat Hubungan \\
\hline $0,00-0,20$ & Sangat Lemah \\
\hline $0,21-0,40$ & Lemah \\
\hline $0,41-0,70$ & Kuat \\
\hline $0,71-0,90$ & Sangat Kuat \\
\hline $0,91-0,99$ & Kuat Sekali \\
\hline 1 & Sempurna \\
\hline
\end{tabular}

Sumber: (Sujarweni, 2015) 


\section{Uji Koefisien Determinasi}

Analisis korelasi dilanjutkan dengan menghitung koefisien determinasi. Menurut Hasan, koefisien determinasi menyatakan bahwa, "penyebab perubahan variabel $Y$ yang datang dari variabel $X$, sebesar kuadrat koefisien korelasinya”. Koefisien determinasi ini menjelaskan besarnya pengaruh nilai suatu variabel (variabel $X$ ) terhadap naik/turunnya (variasi) nilai variabel lainnya (variabel Y). Dirumuskan sebagai berikut: (Hasan, 2016)

Keterangan :

$$
K D=r^{2} x 100 \%
$$

$\mathrm{KD}=$ Koefisien Determinasi

$\mathrm{r} \quad=$ Nilai koefisien korelasi

Nilai koefisien penentu ini terletak antara 0 dan $+1(0 \leq \mathrm{KP} \leq+1)$.

\section{Uji Anova atau Uji F}

Menurut Siregar menyatakan bahwa, "One way anova (analisis ragam satu arah) biasanya digunakan untuk menguji rata-rata atau pengaruh perlakuan dari suatu percobaan yang menggunakan 1 faktor, di mana 1 faktor tersebut memiliki 3 atau lebih banyak kelompok". Disebut satu arah karena peneliti dalam penelitiannya hanya berkepentingan dengan 1 faktor saja atau juga dapat dikatakan one way anova (analisis ragam satu arah) mengelompokkan data berdasarkan satu kriteria saja.

One way anova (analisis ragam satu arah) memiliki kaidah pengujian yaitu jika $\mathrm{F}$ hitung $\leq \mathrm{F}$ tabel maka $\mathrm{H}_{\mathrm{o}}$ diterima, sedangkan jika $\mathrm{F}$ hitung > F tabel maka $\mathrm{H}_{\mathrm{o}}$ ditolak. (Siregar, 2015)

\section{Persamaan Regresi}

Menurut Sujarweni menyatakan bahwa, "regresi bertujuan untuk menguji pengaruh antara variabel 1 dengan variabel lain. Variabel yang dipengaruhi disebut variabel tergantung atau dependen. Sedangakn variabel yang mempengaruhi disebut variabel bebas atau independen." Model persamaan regresi linier sederhana dapat dirumuskan sebagai berikut: (Sujarweni, 2015)

Dimana:

$$
Y=a+b X
$$

Keterangan:

$$
\begin{gathered}
a=\frac{\left(\sum x^{2}\right)\left(\sum y\right)-\left(\sum x\right)\left(\sum x y\right)}{n \sum x^{2}-\left(\sum x\right)^{2}} \\
b=\frac{n \sum x y-\left(\sum x\right)\left(\sum y\right)}{n \sum x^{2}-\left(\sum x\right)^{2}}
\end{gathered}
$$

$\mathrm{Y} \quad=$ variable dependen

$\mathrm{a} \quad=$ nilai konstanta

$\mathrm{b}=$ nilai koefisien regresi

$\mathrm{X}=$ variable independen

$\Sigma \mathrm{x}=$ jumlah total data variabel bebas

$\Sigma \mathrm{x}^{2}=$ jumlah total kuadrat data variabel bebas

$\Sigma y=$ jumlah total data variabel terikat

$\Sigma \mathrm{y}^{2}=$ jumlah total kuadrat data variabel terikat

$\Sigma x y=$ jumlah total perkalian variabel bebas dan terikat

$\mathrm{n} \quad=$ jumlah sampel

\section{Uji T}

Menurut Arifin menyatakan bahwa, "One Sample T Test atau uji T satu sampel merupakan teknik analisis untuk membandingkan satu variabel bebas. Teknik ini digunakan untuk menguji apakah nilai tertentu berbeda secara signifikan atau tidak dengan rata-rata suatu sampel dengan suatu nilai hipotesis". 


\section{JURNAL PETIR}

Vol. 11, No. 2, September 2018, P-ISSN 1978-9262, E-ISSN 2655-5018

One Sample T Test atau uji $\mathrm{T}$ satu sampel memiliki kaidah pengujian yaitu jika $\mathrm{t}$ hitung $<\mathrm{t}$ tabel maka $\mathrm{H}_{\mathrm{o}}$ diterima, sedangkan jika $t$ hitung > t tabel maka $\mathrm{H}_{\mathrm{o}}$ ditolak. (Arifin, 2017)

\section{HASIL DAN ANALISA}

Apotek K24 adalah usaha yang bergerak di bidang farmasi dalam bentuk waralaba atau franchise. Untuk mencapai tujuan yang maksimal di dalam suatu apotek harus dilakukan pengolahan yang baik dan penyerahan perbekalan farmasi lainnya. Pelayanan informasi mengenai perbekalan farmasi lainnya seperti pelayanan informasi tentang obat dan perbekalan farmasi yang diberikan tenaga-tenaga kesehatan lainnya maupun kepada masyarakat dan pengamatan dan pelaporan informasi mengenai khasiat, keamanan, bahaya suatu obat dan perbekalan lainnya.

Dalam pengadaan barang (pembelian), berhasil tidaknya tujuan usaha tergantung kepada kebijaksanaan pembelian. Pembelian harus menyesuaikan dengan hasil penjualan sehingga ada keseimbangan antara penjualan dan pembelian. Selain itu harus sesuai dan cukup ekonomis dilihat dari segi penggunaan dana yang tersedia.

Dalam penyimpanan barang, obat atau barang dagangan yang sudah dibeli tidak semuanya langsung dijual ke konsumen, oleh karena itu harus disimpan dalam gudang terlebih dahulu. Obat yang disimpan dalam gudang dikelompokkan antara obat berupa serbuk, setengah padat dan cair. Disusun berdasarkan abjad, pabrik yang membuat atau menurut persediaannya. Model lemari atau rak yang digunakan berbentuk rumah kotak-kotak selain menghemat ruang, tempat kerja pun menjadi rapi dan bersih. Lemari atau rak yang digunakan dapat terbuat dari kayu dan besi. Penyusunan obat dipakai sistem FIFO (First In First Out), artinya obat-obatan yang masuk terebih dahulu ke gudang, terlebih dahulu keluarnya. Jadi, yang terlebih dahulu masuk diletakkan di depan sedangkan yang terakhir masuk diletakkan dibelakang.

Dalam hal penjualan sebuah apotek perlu memperhatikan hal-hal yang dapat menarik para pembeli obat, antara lain dengan ruang tunggu yang diatur dengan baik, menyenangkan, penerangan yang cukup pada malam hari, pelayanan yang ramah, baik dan cepat.

Pelayanan di apotek meliputi pelayanan resep dan non resep. Dalam pelayanan resep apoteker wajib memberi informasi yang berkaitan dengan cara penggunaan obat, dosis, dan frekuensi pemakaian dan kemungkinan efek samping.

\section{Populasi dan Sampel}

Dalam penelitian ini populasi adalah seluruh konsumen yang pernah membeli produk (obat, vitamin atau alat kesehatan) di Apotek K24 Bambu Apus Jakarta Timur. Adapun jumlah konsumen yang datang ke Apotek K24 Bambu Apus Jakarta Timur di bulan April diperkirakan sebanyak 900 orang.

Penentuan penarikan sampel yang digunakan dalam penelitian ini adalah nonprobability sampling, khususnya purposive sampling, dimana elemen populasi dipilih berdasarkan pertimbangan tertentu, yaitu harus konsumen Apotek K24 Bambu Apus Jakarta Timur. Pemberian kuesioner diberikan kepada konsumen yang datang secara langsung ke Apotek K24 Bambu Apus Jakarta Timur.

Untuk menentukan ukuran sampel penelitian dari populasi tersebut dapat menggunakan rumus Slovin, yaitu:

$$
n=\frac{N}{1+n e^{2}}
$$

Dimana:

$n$ = Jumlah sampel

$\mathrm{N}=$ Besaran populasi (dalam waktu satu bulan)

$\mathrm{e}=$ nilai kritis (batas ketelitian) yang diinginkan (persen kelonggaran ketidaktelitian karena kesalahan penarikan sampel).

$$
n=\frac{900}{1+900(10 \%)^{2}}
$$




$$
\begin{gathered}
n=\frac{900}{1+900(0,01)} \\
n=\frac{900}{10} \\
n=90
\end{gathered}
$$

Dengan demikian jumlah sampel dalam penelitian ini sebanyak 90 responden.

\section{Karakteristik Responden}

Responden yang menjadi sampel penelitian ini sebanyak 90 orang. Profil responden terdiri atas jenis kelamin, usia, tingkat pendidikan, profesi, pendapatan atau penghasilan.

Setelah melakukan penyebaran kuesioner maka peneliti memperoleh data mengenai gambaran atau profil konsumen Apotek K24 Bambu Apus Jakarta Timur:

\section{Jenis Kelamin}

Tabel IV.1. Kelompok responden berdasarkan jenis kelamin

\begin{tabular}{|c|c|c|}
\hline Keterangan & Frekuensi & Persentase $\%$ \\
\hline Laki-laki & 34 & $37,8 \%$ \\
\hline Perempuan & 56 & $62,2 \%$ \\
\hline Total & 90 & $100 \%$ \\
\hline
\end{tabular}

Sumber : Hasil Pengolahan Data Menggunakan SPSS 22.0, Juni 2017

Dari tabel di atas dapat dilihat bahwa responden, dalam hal ini sebagai konsumen Apotek K24 Baambu Apus Jakarta Timur sebagian besar adalah perempuan dengan persentase sebesar 62,2\% sedangkan konsumen laki-laki dengan persentase 37,8\%. Hal ini dapat menggambarkan bahwa secara umum konsumen Apotek K24 Bambu Apus Jakarta Timur di dominasi oleh perempuan.

\section{Usia}

Tabel IV.2, Kelompok responden berdasarkan usia

\begin{tabular}{|c|c|c|}
\hline Keterangan & Frekuensi & Persentase \% \\
\hline$<20$ tahun & 15 & $16,7 \%$ \\
\hline $21-31$ tahun & 37 & $41,1 \%$ \\
\hline $32-42$ tahun & 27 & $30,0 \%$ \\
\hline $43-53$ tahun & 11 & $12,2 \%$ \\
\hline Total & 90 & $100 \%$ \\
\hline
\end{tabular}

Sumber : Hasil Pengolahan Data Menggunakan SPSS 22.0, Juni 2017

Dari tabel di atas dapat disimpulkan bahwa persentase usia responden terdiri dari $16,7 \%$ berumur $<20$ tahun, $41,1 \%$ berumur $21-31$ tahun, $30,0 \%$ berumur $32-42$ tahun, $12,2 \%$ berumur $43-$ 53 tahun. Berdasarkan data tersebut menunjukkan bahwa kebanyakan konsumen Apotek K24 Bambu Apus Jakarta Timur berusia 21-31 tahun. 


\section{Tingkat Pendidikan}

Tabel IV.3. Kelompok responden berdasarkan tingkat pendidikan

\begin{tabular}{|c|c|c|}
\hline Keterangan & Frekuensi & Persentase \% \\
\hline SMA & 17 & $18,9 \%$ \\
\hline D1-D3 & 33 & $36,7 \%$ \\
\hline S1 & 31 & $34,4 \%$ \\
\hline S2 & 9 & $10,0 \%$ \\
\hline Total & 90 & $100 \%$ \\
\hline
\end{tabular}

Sumber : Hasil Pengolahan Data Menggunakan SPSS 22.0, Juni 2017

Dari tabel di atas dapat dilihat bahwa sebagian besar responden memiliki persentase tingkat pendidikan 18,9\% SMA, 36,7\% D1-D3, 34,4\% S1, dan 10,0\% S2. Berdasarkan data tersebut menunjukkan bahwa kebanyakan konsumen Apotek K24 Bambu Apus Jakarta Timur di dominasi dengan tingkat pendidikan D1-D3

\section{Profesi/pekerjaan}

Tabel IV.4. Kelompok responden berdasarkan profesi/pekerjaan

\begin{tabular}{|c|c|c|}
\hline Keterangan & Frekuensi & Persentase \% \\
\hline Pelajar/mahasiswa & 18 & $20,0 \%$ \\
\hline Karyawan swasta & 31 & $34,4 \%$ \\
\hline Ibu rumah tangga & 16 & $17,8 \%$ \\
\hline Wiraswasta & 17 & $18,9 \%$ \\
\hline Lain-lain & 8 & $8,9 \%$ \\
\hline Total & 90 & $100 \%$ \\
\hline
\end{tabular}

Sumber : Hasil Pengolahan Data Menggunakan SPSS 22.0, Juni 2017

Dari tabel di atas dapat disimpulkan bahwa persentase profesi/pekerjaan responden terdiri dari 20,0\% pelajar/mahasiswa, 34,4\% karyawan swasta, 17,8\% ibu rumah tangga, 18,9\% wiraswasta, dan 8,9\% lain-lain seperti PNS. Berdasarkan data tersebut menunjukkan bahwa kebanyakan konsumen Apotek K24 Bambu Apus Jakarta Timur bekerja sebagai karyawan swasta.

\section{Pendapatan/penghasilan}

Tabel IV.5. Kelompok responden berdasarkan profesi/pekerjaan

\begin{tabular}{|c|c|c|}
\hline Keterangan & Frekuensi & Persentase \% \\
\hline Rp 0-Rp 1.000.000 & 16 & $17,8 \%$ \\
\hline Rp 2.000.000-Rp 3.000.000 & 38 & $42,2 \%$ \\
\hline Rp 4.000.000-Rp 5.000.000 & 25 & $27,8 \%$ \\
\hline Rp 6.000.000-Rp 7.000.000 & 11 & $12,2 \%$ \\
\hline Total & 90 & $100 \%$ \\
\hline
\end{tabular}

Sumber : Hasil Pengolahan Data Menggunakan SPSS 22.0, Juni 2017

Dari tabel di atas dapat disimpulkan bahwa persentase pendapatan/penghasilan responden terdiri dari 17,8\% Rp 0-Rp 1.000.000, 42,2\% Rp 2.000.000-Rp 3.000.000, 27,8\% Rp 4.000.000$\mathrm{Rp} 5.000 .000$, dan $12,2 \% \mathrm{Rp} 6.000 .000-\mathrm{Rp}$ 7.000.000. Hal ini dapat menggambarkan bahwa 
kebanyakan pendapatan/penghasilan konsumen Apotek K24 Bambu Apus Jakarta Timur berkisar antara $\mathrm{Rp} 2.000 .000-\mathrm{Rp} 3.000 .000$.

Konsumen Apotek K24 Bambu Apus Jakarta Timur di dominasi oleh konsumen yang memiliki penghasilan yang berkisar Rp 2.000.000-Rp 3.000.000 karena pada penghasilan tersebut biasanya diperoleh dari kalangan konsumen yang sudah bekerja dan berumah tangga.

\section{Uji Instrumen Penelitian}

\section{Uji validitas}

Uji validitas dilakukan dengan menguji pada sebanyak 90 responden untuk menentukan valid atau tidaknya item-item pertanyaan pada kuesioner. Hasil uji validitas dengan rumus Product Moment dihitung dengan menggunakan bantuan program SPSS 22.0.

Item pertanyaan kuesioner dianggap valid jika nilai $r$ hitung $>r$ tabel. Nilai $r$ tabel dicari dengan cara menggunakan tingkat signifikansi $0,10 \mathrm{dan} \mathrm{df}=\mathrm{n}-2$, yaitu $90-2=88$, dan diketahui nilai $r$ tabel adalah 0,1745 .

\section{a. Uji Validitas Variabel Pelayanan Prima}

Variabel pelayanan prima diukur dengan 8 item pertanyaan yang uji validitasnya menghasilkan output dari program SPSS sebagai berikut:

Tabel IV.6. Hasil Uji Validitas SPSS Variabel Pelayanan Prima

\begin{tabular}{|c|l|c|c|}
\hline Item & $\mathbf{r}_{\text {hitung }}$ & $\mathbf{r}_{\text {tabel }}$ & Keterangan \\
\hline \multicolumn{4}{|c|}{ Pelayanan Prima $(\mathbf{X})$} \\
\hline Soal 1 & 0,396 & 0,1745 & Valid \\
\hline Soal 2 & 0,524 & 0,1745 & Valid \\
\hline Soal 3 & 0,581 & 0,1745 & Valid \\
\hline Soal 4 & 0,578 & 0,1745 & Valid \\
\hline Soal 5 & 0,544 & 0,1745 & Valid \\
\hline Soal 6 & 0,521 & 0,1745 & Valid \\
\hline Soal 7 & 0,506 & 0,1745 & Valid \\
\hline Soal 8 & 0,421 & 0,1745 & Valid \\
\hline
\end{tabular}

Sumber : Hasil Pengolahan Data Menggunakan SPSS 22.0, Juni 2017

\section{b. Uji Validitas Variabel Kepuasan Konsumen}

Variabel kepuasan konsumen diukur dengan 8 item pertanyaan yang uji validitasnya menghasilkan output dari program SPSS sebagai berikut:

Tabel IV.7. Hasil Uji Validitas SPSS Variabel Kepuasan Konsumen

\begin{tabular}{|c|c|c|c|}
\hline Item & $\mathbf{r}_{\text {hitung }}$ & $\mathbf{r}_{\text {tabel }}$ & Keterangan \\
\hline \multicolumn{4}{|c|}{ Kepuasan Konsumen (Y) } \\
\hline Soal 1 & 0,514 & 0,1745 & Valid \\
\hline Soal 2 & 0,433 & 0,1745 & Valid \\
\hline Soal 3 & 0,654 & 0,1745 & Valid \\
\hline Soal 4 & 0,523 & 0,1745 & Valid \\
\hline Soal 5 & 0,456 & 0,1745 & Valid \\
\hline Soal 6 & 0,386 & 0,1745 & Valid \\
\hline Soal 7 & 0,472 & 0,1745 & Valid \\
\hline Soal 8 & 0,496 & 0,1745 & Valid \\
\hline
\end{tabular}

Sumber : Hasil Pengolahan Data Menggunakan SPSS 22.0, Juni 2017 


\section{JURNAL PETIR}

Vol. 11, No. 2, September 2018, P-ISSN 1978-9262, E-ISSN 2655-5018

Hasil uji validitas menunjukkan bahwa seluruh item pertanyaan dalam kuesioner mempunyai $r$ hitung > $r$ tabel $(0,1745)$, maka pertanyaan tersebut valid. Dengan demikian, seluruh butir soal yang ada dalam kuesioner dari variabel pelayanan prima dan kepuasan konsumen adalah berjumlah 16 pertanyaan dan dinyatakan valid.

\section{Uji Reliabilitas}

Uji reliabiltas dilakukan dengan menguji masing-masing variabel dengan rumus Cronbach's Alpha. Berikut adalah hasil uji reliabilitas dengan perhitungan menggunakan SPSS 22.0:

Tabel III.8. Hasil Uji Reliabilitas

\begin{tabular}{|c|c|c|c|c|}
\hline No & Variabel & $\begin{array}{c}\text { Cronbach's } \\
\text { Alpha }\end{array}$ & $\begin{array}{c}\text { Interpretasi } \\
\text { Reliabilitas }\end{array}$ & Keterangan \\
\hline 1 & Pelayanan Prima (X) & 0,592 & $0,40-0,60$ & Sedang \\
\hline 2 & Kepuasan Konsumen (Y) & 0,524 & $0,40-0,60$ & Sedang \\
\hline
\end{tabular}

Sumber : Hasil Pengolahan Data Menggunakan SPSS 22.0, Juni 2017

Hasil uji reliabilitas variabel pelayanan prima (X) pada kolom Cronbach's Alpha menunjukkan nilai reliabilitas, yaitu 0,592 dimana angka 0,592 mempunyai interpretasi reliabilitas yang sedang karena termasuk dalam rentang nilai $0,40-0,60$, maka seluruh item pertanyaan dari variabel pelayanan prima $(\mathrm{X})$ dinyatakan reliabel, yang berarti seluruh item pada kuesioner dapat dipercaya.

Hasil uji reliabilitas variabel kepuasan konsumen (Y) pada kolom Cronbach's Alpha menunjukkan nilai reliabilitas, yaitu 0,524 dimana angka 0,524 mempunyai interpretasi reliabilitas yang sedang karena termasuk dalam rentang nilai $0,40-0,60$, maka seluruh item pertanyaan dari variabel kepuasan konsumen $(\mathrm{Y})$ dinyatakan reliabel, yang berarti seluruh item pada kuesioner dapat dipercaya.

\section{Data hasil kuesioner Pelayanan Prima}

Untuk mengukur pelayanan yang diberikan oleh pihak Apotek K24 Bambu Apus Jakarta Timur digunakan indikator-indikator yang menjadi tolak ukur kuesioner. Metode yang diambil dalam penelitian ini adalah metode pengukuran likert, dimana setiap pertanyaan mengandung lima alternatif jawaban. Adapun bobot nilai dalam penelitian ini adalah sangat setuju diberi bobot nilai 5 , setuju diberi bobot nilai 4 , kurang setuju diberi bobot nilai 3, tidak setuju diberi bobot nilai 2 , sangat tidak setuju diberi bobot nilai 1 .

Tabel IV.9. Pramuniaga selalu menyapa dengan sikap yang ramah, sopan dan santun ketika bertemu dengan konsumen

\begin{tabular}{|c|c|c|}
\hline Kategori & Jumlah & Persentase \% \\
\hline Sangat setuju & 57 & $63,3 \%$ \\
\hline Setuju & 33 & $36,7 \%$ \\
\hline Kurang setuju & 0 & 0 \\
\hline Tidak setuju & 0 & 0 \\
\hline Sangat tidak setuju & 0 & 0 \\
\hline Total & $\mathbf{9 0}$ & $\mathbf{1 0 0 \%}$ \\
\hline
\end{tabular}

Sumber : Hasil Pengolahan Data Menggunakan SPSS 22.0, Juni 2017

Pada tabel IV.9 menunjukkan bahwa 63,3\% responden menyatakan sangat setuju, 36,7\% responden menyatakan setuju. Berdasarkan perhitungan data diatas menunjukkan kriteria sangat setuju, artinya mayoritas konsumen sangat setuju bahwa pelayanan yang diberikan pramuniaga ketika bertemu konsumen sudah menunjukkan hasil yang sangat baik. 
Tabel IV.10. Pramuniaga sabar dalam memberikan informasi dalam melayani konsumen

\begin{tabular}{|c|c|c|}
\hline Kategori & Jumlah & Persentase \% \\
\hline Sangat setuju & 26 & $28,9 \%$ \\
\hline Setuju & 62 & $68,9 \%$ \\
\hline Kurang setuju & 2 & $2,2 \%$ \\
\hline Tidak setuju & 0 & 0 \\
\hline Sangat tidak setuju & 0 & 0 \\
\hline Total & $\mathbf{9 0}$ & $\mathbf{1 0 0 \%}$ \\
\hline
\end{tabular}

Sumber : Hasil Pengolahan Data Menggunakan SPSS 22.0, Juni 2017

Pada tabel IV.10 menunjukkan bahwa 68,9\% responden menyatakan setuju, 28,9\% responden menyatakan sangat setuju. Akan tetapi ada 2,2\% responden menyatakan kurang setuju dengan sikap pramuniaga. Menurut responden tersebut hal ini dikarenakan tidak sabar dalam memberikan informasi tentang produk yang konsumen beli. Tetapi secara umum dapat dikatakan bahwa sikap sabar pramuniaga dalam memberikan informasi dalam melayani konsumen sudah menunjukkan hasil yang baik.

Tabel IV.11. Pramuniaga berpenampilan sesuai dengan seragam yang diberlakukan

\begin{tabular}{|c|c|c|}
\hline Kategori & Jumlah & Persentase \% \\
\hline Sangat setuju & 24 & $26,7 \%$ \\
\hline Setuju & 62 & $68,9 \%$ \\
\hline Kurang setuju & 4 & $4,4 \%$ \\
\hline Tidak setuju & 0 & 0 \\
\hline Sangat tidak setuju & 0 & 0 \\
\hline Total & $\mathbf{9 0}$ & $\mathbf{1 0 0 \%}$ \\
\hline
\end{tabular}

Sumber : Hasil Pengolahan Data Menggunakan SPSS 22.0, Juni 2017

Pada tabel IV.11 menunjukkan bahwa 68,9\% responden menyatakan setuju, 26,7\% responden menyatakan sangat setuju dan $4,4 \%$ responden menyatakan kurang setuju bahwa penampilan pramuniaga sesuai dengan seragam yang diberlakukan. Menurut responden tersebut ada beberapa seragam pegawai terlihat sudah sedikit kotor.

Secara umum dapat dikatakan bahwa penampilan pramuniaga sesuai dengan seragam yang diberlakukan sudah menunjukkan hasil yang baik.

Tabel IV.12. Pramuniaga selalu mendengarkan dan memahami kebutuhan konsumen saat bertanya

\begin{tabular}{|c|c|c|}
\hline Kategori & Jumlah & Persentase \% \\
\hline Sangat setuju & 31 & $34,4 \%$ \\
\hline Setuju & 53 & $58,9 \%$ \\
\hline Kurang setuju & 6 & $6,7 \%$ \\
\hline Tidak setuju & 0 & 0 \\
\hline Sangat tidak setuju & 0 & 0 \\
\hline Total & $\mathbf{9 0}$ & $\mathbf{1 0 0 \%}$ \\
\hline
\end{tabular}

Sumber : Hasil Pengolahan Data Menggunakan SPSS 22.0, Juni 2017

Pada tabel IV.12 menunjukkan bahwa 58,9\% responden menyatakan setuju, 34,4\% responden menyatakan sangat setuju dan $6,7 \%$ responden menyatakan kurang setuju. Menurut responden tersebut mengatakan bahwa ada beberapa pramuniaga yang kurang memahami kebutuhankonsumen seperti pada ssat konsumen menanyakan tentang produk-produk tertentu. 
Tetapi secara umum disimpulkan bahwa pramuniaga selalu mendengarkan dan memahami kebutuhankonsumen saat bertanya sudah menunjukkan hasil yang baik.

Tabel IV.13. Pramuniaga selalu mengingatkan kepada konsumen agar melakukan konsultasi jika terjadi kendala

\begin{tabular}{|c|c|c|}
\hline Kategori & Jumlah & Persentase \% \\
\hline Sangat setuju & 17 & $18,9 \%$ \\
\hline Setuju & 58 & $64,4 \%$ \\
\hline Kurang setuju & 15 & $16,7 \%$ \\
\hline Tidak setuju & 0 & 0 \\
\hline Sangat tidak setuju & 0 & 0 \\
\hline Total & $\mathbf{9 0}$ & $\mathbf{1 0 0 \%}$ \\
\hline
\end{tabular}

Sumber : Hasil Pengolahan Data Menggunakan SPSS 22.0, Juni2017

Pada tabel IV.13 menunjukkan bahwa 64,4\% responden menyatakan setuju, 18,9\% responden menyatakan sangat setuju dan $16,7 \%$ responden menyatakan kurang setuju. Beberapa responden menyatakan bahwa ada beberapa pramuniaga yang tidak menyarankan agar berkonsultasi jika terjadi kendala. Secara keseluruhan dapat disimpulkan bahwa pramuniaga selalu mengingatakan konsumen agar berkonsultasi jika terjadi kendala sudah menunjukkan hasil yang baik.

Tabel IV.14. Pramuniaga selalu cekatan dalam mencari kebutuhan produk yang diinginkan konsumen

\begin{tabular}{|c|c|c|}
\hline Kategori & Jumlah & Persentase \% \\
\hline Sangat setuju & 25 & $27,8 \%$ \\
\hline Setuju & 53 & $58,9 \%$ \\
\hline Kurang setuju & 12 & $13,3 \%$ \\
\hline Tidak setuju & 0 & 0 \\
\hline Sangat tidak setuju & 0 & 0 \\
\hline Total & $\mathbf{9 0}$ & $\mathbf{1 0 0 \%}$ \\
\hline
\end{tabular}

Sumber : Hasil Pengolahan Data Menggunakan SPSS 22.0, Juni 2017

Pada tabel IV.14 menunjukkan bahwa 58,9\% responden menyatakan setuju, 27,8\% responden menyatakan sangat setuju dan $13,3 \%$ responden menyatakan kurang setuju. Menurut responden yang kurang setuju menyatakan bahwa ada pramuniaga yang kurang tanggap terhadap apa yang diminta oleh konsumen. Secara umum dapat disimpulkan bahwa pramuniaga selalu cekatan dalam mencari kebutuhan produk yang diinginkan konsumen sudah menunjukkan hasil yang baik.

Tabel IV.15. Pramuniaga selalu menegaskan kembali kepada konsumen tentang produk yang dibeli

\begin{tabular}{|c|c|c|}
\hline Kategori & Jumlah & Persentase \% \\
\hline Sangat setuju & 40 & $44,4 \%$ \\
\hline Setuju & 46 & $51,1 \%$ \\
\hline Kurang setuju & 4 & $4,4 \%$ \\
\hline Tidak setuju & 0 & 0 \\
\hline Sangat tidak setuju & 0 & 0 \\
\hline Total & $\mathbf{9 0}$ & $\mathbf{1 0 0 \%}$ \\
\hline
\end{tabular}

Sumber : Hasil Pengolahan Data Menggunakan SPSS 22.0, Juni 2017

Pada tabel IV.15 menunjukkan bahwa 51,1\% responden menyatakan setuju, $44,4 \%$ responden menyatakan sangat setuju dan $4,4 \%$ responden menyatakan tidak setuju. Berdasarkan data di atas menunjukkan kriteria setuju, bahwa pramuniaga selalu menegaskan kembali kepada konsumen tentang produk yang dibeli. 
Tabel IV.16. Pramuniaga mengucapkan terima kasih pada akhir pelayanan

\begin{tabular}{|c|c|c|}
\hline Kategori & Jumlah & Persentase \% \\
\hline Sangat setuju & 50 & $55,6 \%$ \\
\hline Setuju & 40 & $44,4 \%$ \\
\hline Kurang setuju & 0 & 0 \\
\hline Tidak setuju & 0 & 0 \\
\hline Sangat tidak setuju & 0 & 0 \\
\hline Total & $\mathbf{9 0}$ & $\mathbf{1 0 0 \%}$ \\
\hline
\end{tabular}

Sumber : Hasil Pengolahan Data Menggunakan SPSS 22.0, Juni 2017

Pada tabel III.16 menunjukkan bahwa 55,6\% responden menyatakan sangat setuju, 44,4\% responden menyatakan setuju.Berdasarkan data di atas menunjukkan kriteria sangat setuju, bahwa pramuniaga mengucapkan terima kasih kepada konsumen pada akhir pelayanan.

\section{Data hasil kuesioner Kepuasan Konsumen}

Untuk mengukur kepuasan konsumen yang menjadi konsumen Apotek K24 Bambu Apus Jakarta Timur digunakan indikator-indikator yang menjadi tolak ukur. Metode yang diambil dalam penelitian ini adalah metode pengukuran likert, dimana setiap pertanyaan mengandung lima alternatif jawaban. Adapun bobot nilai dalam penelitian ini adalah sangat puas diberi bobot nilai 5 , puas diberi bobot nilai 4 , kurang puas diberi bobot nilai 3, tidak puas diberi bobot nilai 2 , sangat tidak puas diberi bobot nilai 1 .

Tabel IV.17. Apotek K24 menjual produk (obat, vitamin atau alat kesehatan) Dengan kemasan produk yang baik (tidak cacat)

\begin{tabular}{|c|c|c|}
\hline Kategori & Jumlah & Persentase \% \\
\hline Sangat puas & 42 & $46,7 \%$ \\
\hline Puas & 32 & $35,6 \%$ \\
\hline Kurang puas & 16 & $17,8 \%$ \\
\hline Tidak puas & 0 & 0 \\
\hline Sangat tidak puas & 0 & 0 \\
\hline Total & $\mathbf{9 0}$ & $\mathbf{1 0 0 \%}$ \\
\hline
\end{tabular}

Sumber : Hasil Pengolahan Data Menggunakan SPSS 22.0, Juni 2017

Dari tabel IV.17 menunjukkan bahwa 46,7\% responden menyatakan sangat puas, 35,6\% responden menyatakan puas dan $17,8 \%$ responden menyatakan kurang puas. Berdasarkan data di atas menunjukkan kriteria sangat puas, artinya konsumen sangat puas karena Apotek K24 menjual produk (obat, vitamin atau alat kesehatan) dengan kemasan produk yang baik (tidak cacat).

Tabel IV.18. Ketahanan produk (obat, vitamin atau alat kesehatan) yang dijual Apotek K24 sesuai dengan tanggal kadaluarsa yang tertera pada kemasan

\begin{tabular}{|c|c|c|}
\hline Kategori & Jumlah & Persentase \% \\
\hline Sangat puas & 21 & $23,3 \%$ \\
\hline Puas & 68 & $75,6 \%$ \\
\hline Kurang puas & 1 & $1,1 \%$ \\
\hline Tidak puas & 0 & 0 \\
\hline Sangat tidak puas & 0 & 0 \\
\hline Total & $\mathbf{9 0}$ & $\mathbf{1 0 0 \%}$ \\
\hline
\end{tabular}

Sumber : Hasil Pengolahan Data Menggunakan SPSS 22.0, Juni 2017

Dari tabel IV.18 menunjukkan bahwa 75,6\% responden menyatakan puas, $23,3 \%$ responden menyatakan sangat puas dan $17,8 \%$ responden menyatakan kurang puas. Berdasarkan data di atas menunjukkan kriteria puas, artinya konsumen puas karena ketahanan produk (obat, vitamin atau 
alat kesehatan) yang dijual Apotek K24 sesuai dengan tanggal kadaluarsa yang tertera pada kemasan.

Tabel IV.19. Pramuniaga mampu memberikan pelayanan yang sigap dan ramah

\begin{tabular}{|c|c|c|}
\hline Kategori & Jumlah & Persentase \% \\
\hline Sangat puas & 29 & $32,2 \%$ \\
\hline Puas & 56 & $62,2 \%$ \\
\hline Kurang puas & 5 & $5,6 \%$ \\
\hline Tidak puas & 0 & 0 \\
\hline Sangat tidak puas & 0 & 0 \\
\hline Total & $\mathbf{9 0}$ & $\mathbf{1 0 0 \%}$ \\
\hline
\end{tabular}

Sumber : Hasil Pengolahan Data Menggunakan SPSS 22.0, Juni 2017

Dari tabel IV.19 menunjukkan bahwa 62,2\% responden menyatakan puas, 32,2\% responden menyatakan sangat puas dan 5,6\% responden menyatakan kurang puas. Berdasarkan data di atas menunjukkan kriteria puas, artinya konsumen puas karena pramuniaga mampu memberikan pelayanan yang sigap dan ramah kepada konsumen

Tabel IV.20. Pramuniaga mampu memberikan informasi yang lengkap tentang obat yang dibutuhkan

\begin{tabular}{|c|c|c|}
\hline Kategori & Jumlah & Persentase \% \\
\hline Sangat puas & 17 & $18,9 \%$ \\
\hline Puas & 67 & $74,4 \%$ \\
\hline Kurang puas & 6 & $6,7 \%$ \\
\hline Tidak puas & 0 & 0 \\
\hline Sangat tidak puas & 0 & 0 \\
\hline Total & $\mathbf{9 0}$ & $\mathbf{1 0 0 \%}$ \\
\hline
\end{tabular}

Sumber : Hasil Pengolahan Data Menggunakan SPSS 22.0, Juni 2017

Dari tabel IV.20 menunjukkan bahwa 74,4\% responden menyatakan puas, $18,9 \%$ responden menyatakan sangat puas dan $6,7 \%$ responden menyatakan kurang puas. Berdasarkan data di atas menunjukkan kriteria puas, artinya konsumen puas karena pramuniaga mampu memberikan informasi yang lengkap kepada konsumen pada saat bertanya mengenai obat yang dibutuhkan.

Tabel IV.21. Harga produk (obat, vitamin atau alat kesehatan) di Apotek K24 lebih murah dari apotek lain

\begin{tabular}{|c|c|c|}
\hline Kategori & Jumlah & Persentase \% \\
\hline Sangat puas & 11 & $12,2 \%$ \\
\hline Puas & 61 & $67,8 \%$ \\
\hline Kurang puas & 18 & $20,0 \%$ \\
\hline Tidak puas & 0 & 0 \\
\hline Sangat tidak puas & 0 & 0 \\
\hline Total & $\mathbf{9 0}$ & $\mathbf{1 0 0 \%}$ \\
\hline
\end{tabular}

Sumber : Hasil Pengolahan Data Menggunakan SPSS 22.0, Juni 2017

Dari tabel IV.21 menunjukkan bahwa 67,8\% responden menyatakan puas, 20,0\% responden menyatakan kurang puas dan $12,2 \%$ responden menyatakan sangat puas. Berdasarkan data di atas menunjukkan kriteria puas, artinya konsumen puas karena harga produk (obat, vitamin atau alat kesehatan) yang ditawarkan Apotek K24 lebih murah dari apotek lain. 
Tabel IV.22. Apotek K24 memberikan potongan harga pada produk (obat, vitamin atau alat kesehatan) tertentu

\begin{tabular}{|c|c|c|}
\hline Kategori & Jumlah & Persentase \% \\
\hline Sangat puas & 8 & $8,9 \%$ \\
\hline Puas & 74 & $82,2 \%$ \\
\hline Kurang puas & 8 & $8,9 \%$ \\
\hline Tidak puas & 0 & 0 \\
\hline Sangat tidak puas & 0 & 0 \\
\hline Total & $\mathbf{9 0}$ & $\mathbf{1 0 0 \%}$ \\
\hline
\end{tabular}

Sumber : Hasil Pengolahan Data Menggunakan SPSS 22.0, Juni 2017

Dari tabel IV.22 menunjukkan bahwa 82,2\% responden menyatakan puas, 8,9\% responden menyatakan sangat puas dan $8,9 \%$ responden menyatakan kurang puas. Berdasarkan data di atas menunjukkan kriteria puas, artinya konsumen puas karena Apotek K24 memberikan potongan harga pada produk (obat, vitamin atau alat kesehatan) tertentu, seperti vitamin untuk anak-anak dan untuk orang dewasa.

Tabel IV.23. Lokasi apotek K24 dapat dijangkau dengan mudah

\begin{tabular}{|c|c|c|}
\hline Kategori & Jumlah & Persentase \% \\
\hline Sangat puas & 15 & $16,7 \%$ \\
\hline Puas & 58 & $64,4 \%$ \\
\hline Kurang puas & 17 & $18,9 \%$ \\
\hline Tidak puas & 0 & 0 \\
\hline Sangat tidak puas & 0 & 0 \\
\hline Total & $\mathbf{9 0}$ & $\mathbf{1 0 0 \%}$ \\
\hline
\end{tabular}

Sumber : Hasil Pengolahan Data Menggunakan SPSS 22.0, Juni 2017

Dari tabel IV.23 menunjukkan bahwa 64,4\% responden menyatakan puas, 18,9\% responden menyatakan kurang puas dan $16,7 \%$ responden menyatakan sangat puas. Berdasarkan data di atas menunjukkan kriteria puas, artinya konsumen puas karena lokasi apotek K24 dapat dijangkau dengan mudah dan strategis dengan tempat tinggal konsumen yang ingin membeli obat.

Tabel IV.24. Pelayanan di kasir dan meracik resep obat di apotek K24 tidak perlu menunggu lama

\begin{tabular}{|c|c|c|}
\hline Kategori & Jumlah & Persentase \% \\
\hline Sangat puas & 8 & $8,9 \%$ \\
\hline Puas & 79 & $87,8 \%$ \\
\hline Kurang puas & 3 & $3,3 \%$ \\
\hline Tidak puas & 0 & 0 \\
\hline Sangat tidak puas & 0 & 0 \\
\hline Total & $\mathbf{9 0}$ & $\mathbf{1 0 0 \%}$ \\
\hline
\end{tabular}

Sumber : Hasil Pengolahan Data Menggunakan SPSS 22.0, Juni 2017

Dari tabel IV.24 menunjukkan bahwa 87,8\% responden menyatakan puas, 8,9\% responden menyatakan sangat puas dan 3,3\% responden menyatakan kurang puas. Berdasarkan data di atas menunjukkan kriteria puas, artinya konsumen puas karena pelayanan di kasir dan meracik resep obat di apotek K24 tidak perlu menunggu lama.

\section{Tabel Penolong}

Berdasarkan data hasil kuesioner variabel pelayanan prima (X) dan variabel kepuasan konsumen (Y), maka selanjutnya akan dijabarkan mengenai gabungan dari total skor variabel pelayanan prima dan kepuasan konsumen yang disajikan dalam tabel penolong berikut ini: 
Tabel IV. 25. Tabel Penolong

\begin{tabular}{|c|c|c|c|c|c|}
\hline Res. & $\begin{array}{c}\text { Pelayanan } \\
\text { Prima (X) }\end{array}$ & $\begin{array}{c}\text { Kepuasan } \\
\text { Konsumen (Y) }\end{array}$ & XY & $\mathbf{X}^{2}$ & $\mathbf{Y}^{2}$ \\
\hline $\mathbf{9 0}$ & $\mathbf{3 1 0 7}$ & $\mathbf{2 9 6 0}$ & $\mathbf{1 0 2 2 6 1}$ & $\mathbf{1 0 7 7 0 7}$ & $\mathbf{9 7 7 2 8}$ \\
\hline
\end{tabular}

Sumber : Hasil Pengolahan Data Menggunakan Microsoft Excel 2007, Juni 2017

\section{Analisa Pengaruh Pelayanan Prima terhadap Kepuasan Konsumen}

\section{Uji Koefisien Korelasi}

Untuk melihat sejauh mana pengaruh dan hubungan pelayanan prima terhadap kepuasan konsumen pada apotek K24 Bambu Apus Jakarta Timur, maka selanjutnya dilakukan pengolahan kuesioner terhadap dua variabel yang diuji hubungannya yaitu variabel independen (pelayanan prima) dengan variabel dependen (kepuasan konsumen). Nilai koefisien korelasi dapat dihitung dengan rumus korelasi berikut:

$$
\begin{gathered}
r=\frac{n \sum x y-\left(\sum x\right)\left(\sum y\right)}{\sqrt{\left[n \sum x^{2}-\left(\sum x\right)^{2}\right]\left[n \sum y^{2}-\left(\sum y\right)^{2}\right]}} \\
r=\frac{90(102261)-(3107)(2960)}{\sqrt{\left[90(107707)-(3107)^{2}\right]\left[90(97728)-(2960)^{2}\right]}} \\
r=\frac{9203490-9196720}{\sqrt{[9693630-9653449][8795520-8761600]}} \\
r=\frac{6770}{\sqrt{[40181][33920]}} \\
r=\frac{6770}{\sqrt{1362939520}} \\
r=0,18337933
\end{gathered}
$$

Dengan menggunakan bantuan program SPSS versi 22.0 dengan analisis Korelasi Bivariat Pearson Correlation dan output-nya berupa tabel IV.26 berikut ini:

Tabel III.26. Hasil Korelasi

\begin{tabular}{|c|l|r|r|}
\hline \multicolumn{2}{|c|}{} & X & \multicolumn{1}{|c|}{ Y } \\
\hline \multirow{4}{*}{ Pelayanan Prima } & Pearson Correlation & 1 &, 183 \\
\cline { 2 - 4 } & Sig. (2-tailed) & 90 &, 084 \\
\cline { 2 - 4 } & N &, 183 & 90 \\
\hline \multirow{3}{*}{$\begin{array}{c}\text { Kepuasan } \\
\text { Konsumen }\end{array}$} & Pearson Correlation &, 084 & 1 \\
\cline { 2 - 4 } & Sig. (2-tailed) & 90 & 90 \\
\cline { 2 - 4 } & N & & \\
\hline
\end{tabular}

Sumber : Hasil Pengolahan Data Menggunakan SPSS 22.0, Juni 2017

Berdasarkan perhitungan dengan rumus dan tabel IV.26 di atas disimpulkan bahwa hasil uji Pearson Correlation semua faktor-faktor pelayanan prima dengan kepuasan konsumen menunjukkan bahwa terlihat hubungan yang sangat lemah dan searah antar variabel independen (pelayanan prima) dengan variabel dependen (kepuasan konsumen) yaitu sebesar 0,183 yang termasuk kategori 0,00-0,20. 


\section{Uji Koefisien Determinasi}

Koefisien determinasi digunakan untuk melihat berapa persen dari variasi variabel dependen (kepuasan konsumen) dapat diterangkan oleh variasi variabel independen (pelayanan prima). Berikut adalah hasil pengolahan kuesioner terhadap dua variabel yang diuji hubungannya yaitu variabel independen (pelayanan prima) dengan variabel dependen (kepuasan konsumen). Hasil perhitungan nilai koefisien determinasi dengan rumus sebagai berikut:

$$
\begin{gathered}
\boldsymbol{K D}=\boldsymbol{r}^{2} \times \mathbf{1 0 0} \% \\
K D=0,183^{2} \times 100 \% \\
K D=0,034 \times 100 \% \\
K D=3,4 \%
\end{gathered}
$$

Dengan menggunakan program SPSS versi 22.0, maka output-nya berupa tabel IV.27 berikut ini:

Tabel IV.27. Model Summary

\begin{tabular}{|c|c|c|c|c|}
\hline Model & $\mathrm{R}$ & $\mathrm{R}$ Square & $\begin{array}{c}\text { Adjusted R } \\
\text { Square }\end{array}$ & $\begin{array}{c}\text { Std. Error of } \\
\text { the Estimate }\end{array}$ \\
\hline 1 &, $183^{\mathrm{a}}$ &, 034 &, 023 & 2,034 \\
\hline
\end{tabular}

a. Predictors: (Constant), Pelayanan_Prima

b. Dependent Variable: Kepuasan_Konsumen

Sumber : Hasil Pengolahan Data Menggunakan SPSS 22.0, Juni 2017

Pada perhitungan dengan rumus dan tabel IV.27 di atas disimpulkan bahwa besarnya pengaruh variabel pelayanan prima terhadap variabel kepuasan konsumen di Apotek K24 Bambu Apus Jakarta Timur adalah sebesar 3,4\% dan sisanya 96,6\% dipengaruhi oleh variabel-variabel seperti faktor kualitas pelayanan, harga, produk, lokasi.

\section{Persamaan Regresi}

Tabel IV.28. Hasil ANOVA

\begin{tabular}{|l|r|r|r|r|r|}
\hline Model & Sum of Squares & Df & $\begin{array}{c}\text { Mean } \\
\text { Square }\end{array}$ & F & \multicolumn{1}{c|}{ Sig. } \\
\hline $1 \begin{array}{l}\text { Regression } \\
\text { Residual } \\
\text { Total }\end{array}$ & 12,674 & 1 & 12,674 & 3,062 &, $084^{\mathrm{b}}$ \\
\cline { 2 - 6 } & 364,215 & 88 & 4,139 & & \\
\hline
\end{tabular}

a. Dependent Variable: kepuasan konsumen

b. Predictors: (Constant), pelayanan prima

Sumber: Hasil Pengolahan Data Menggunakan SPSS 22.0, Juni 2017

Berdasarkan tabel IV.31 uji anova atau F test digunakan untuk melakukan pengujian hipotesis antara variabel pelayanan prima $(\mathrm{X})$ terhadap variabel kepuasan konsumen (Y) dengan pengujian bahwa nilai F hitung $>\mathrm{F}$ tabel. Dapat diketahui bahwa nilai $\mathrm{F}$ hitung $>\mathrm{F}$ tabel $(3,062>2,760)$ atau dengan model signifikansi (sig) $=0,084<0,10$, yaitu signifikansi lebih kecil dari Alpha. Hasil ini membuktikan bahwa hipotesis adanya pegaruh antara variabel pelayanan prima dan variabel kepuasan konsumen.

Kemudian hasil persamaan regresi linier sederhana dapat dirumuskan sebagai berikut: 


$$
Y=a+b X
$$

Dimana:

$\mathrm{a}=$ Konstanta

$$
\begin{gathered}
a=\frac{\left(\sum x^{2}\right)\left(\sum y\right)-\left(\sum x\right)\left(\sum x y\right)}{n \sum x^{2}-\left(\sum x\right)^{2}} \\
a=\frac{(107707)(2960)-(3107)(102261)}{90(107707)-(3107)^{2}} \\
a=\frac{318812720-317724927}{9693630-9653449} \\
a=\frac{1087793}{40181} \\
a=27,07232274
\end{gathered}
$$

$\mathrm{b}=$ nilai koefisien regresi

$$
\begin{gathered}
b=\frac{n \sum x y-\left(\sum x\right)\left(\sum y\right)}{n \sum x^{2}-\left(\sum x\right)^{2}} \\
b=\frac{90(102261)-(3107)(2960)}{90(107707)-(3107)^{2}} \\
b=\frac{9203490-9196720}{9693630-9653449} \\
b=\frac{6770}{40181} \\
b=0,16848759
\end{gathered}
$$

Dengan menggunakan program SPSS versi 22.0, maka output-nya berupa tabel IV.29 berikut ini:

Tabel IV.29. Regresi Sederhana

\begin{tabular}{|l|r|r|r|r|r|}
\hline \multirow{2}{*}{ Model } & \multicolumn{2}{|c|}{$\begin{array}{c}\text { Unstandardized } \\
\text { Coefficients }\end{array}$} & $\begin{array}{c}\text { Standardized } \\
\text { Coefficients }\end{array}$ & \multirow{2}{*}{ T } & \multirow{2}{*}{ Sig. } \\
\cline { 2 - 5 } & \multicolumn{1}{|c|}{ B } & Std. Error & Beta & & \\
\hline $\begin{array}{c}1 \text { (Constant) } \\
\text { Pelayanan prima }\end{array}$ & 27,072 & 3,331 & & 8,128 &, 000 \\
\cline { 2 - 7 } &, 168 &, 096 &, 183 & 1,750 &, 084 \\
\hline
\end{tabular}

a. Dependent Variable: Kepuasan konsumen

Sumber : Hasil Pengolahan Data Menggunakan SPSS 22.0, Juni 2017

Berdasarkan perhitungan rumus dan tabel IV.29 di atas menggambarkan persamaan regresi Y $=\mathrm{a}+\mathrm{bX}$, dimana kolom $\mathrm{B}$ pada Constant (a) adalah 27,072, sedangkan nilai (b) adalah 0,168, sehingga persamaan regresinya dapat digambarkan sebagai berikut:

$\mathrm{Y}=27,072+0,168 \mathrm{X}$, Dimana jika tidak ada variabel pelayanan prima maka nilai kepuasan konsumen adalah sebesar 27,072. Koefisien regresi sebesar 0,168 menyatakan bahwa setiap penambahan (karena positif) 1 pelayanan prima akan meningkatkan kepuasan konsumen sebesar 0,168. Jika sebaliknya, pelayanan prima menurun sebesar 1, jadi kepuasan konsumen akan mengalami penurunan sebesar 0,168 . Maka, tanda positif akan menyatakan arah hubungan searah, yang dimana kenaikan atau penurunan variabel independen $(X)$ akan mengakibatkan kenaikan atau penurunan variabel dependen $(\mathrm{Y})$

Dan dari tabel regresi sederhana juga akan menggambarkan uji t. Uji t dilakukan untuk melihat apakah terdapat pengaruh antara pelayanan prima terhadap kepuasan konsumen. Uji $t$ dilakukan dengan membandingkan antara t hitung dan $t$ tabel pada tingkat signifikasi $10 \%$. Jika nilai $t$ hitung lebih besar dibandingkan $t$ tabel maka dapatdisimpulkan bahwa variabel dependen (kepuasan konsumen) memiliki pengaruh yang signifikan terhadap variabel independen (pelayanan prima) 
Tabel IV.30. Hasil nilai uji T

\begin{tabular}{|l|r|r|r|r|r|}
\hline \multirow{2}{*}{ Model } & \multicolumn{2}{|c|}{$\begin{array}{c}\text { Unstandardized } \\
\text { Coefficients }\end{array}$} & $\begin{array}{c}\text { Standardized } \\
\text { Coefficients }\end{array}$ & \multirow{2}{*}{ T } & \multirow{2}{*}{ Sig. } \\
\cline { 3 - 5 } & \multicolumn{1}{|c|}{ B } & Std. Error & Beta & & \\
\hline \multirow{2}{*}{$1 \quad \begin{array}{c}\text { (Constant) } \\
\text { Pelayanan prima }\end{array}$} & 27,072 & 3,331 & & 8,128 &, 000 \\
\cline { 2 - 7 } &, 168 &, 096 &, 183 & 1,750 &, 084 \\
\hline
\end{tabular}

Sumber : Hasil Pengolahan Data Menggunakan SPSS 22.0, Juni 2017

\section{Pengambilan Keputusan}

Dengan membandingkan statistik hitung dengan statistik tabel jika statistik $t$ hitung $<$ statistik $\mathrm{t}$ tabel, maka $\mathrm{H}_{\mathrm{o}}$ diterima dan jika statistik t hitung > statistik $\mathrm{t}$ tabel, maka $\mathrm{H}_{\mathrm{o}}$ ditolak.

1. Statistik t hitung

Dari tabel output terlihat bahwa t hitung adalah 1,750

2. Statistik $t$ tabel

a. $\quad$ Tingkat signifikasi $(a)=10 \%$

b. Dengan rumus $\mathrm{t}=\mathrm{n}-2$ atau $90-2=88$

Untuk t tabel didapat angka 1,662

\section{Keputusan:}

Karena $\mathrm{t}$ hitung $>\mathrm{t}$ tabel $(1,750>1,662)$ maka $\mathrm{H}_{\mathrm{o}}$ ditolak dan $\mathrm{H}_{\mathrm{a}}$ diterima. Dengan demikian $\mathrm{t}$ hitung lebih besar dari t tabel $(1,750>1,662)$ ini berarti $\mathrm{H}_{\mathrm{a}}$ diterima dan $\mathrm{H}_{\mathrm{o}}$ ditolak, dengan kata lain pelayanan prima berpengaruh terhadap kepuasan konsumen.

\section{KESIMPULAN DAN SARAN}

\section{Kesimpulan}

Berdasarkan hasil penelitian tentang pelayanan prima terhadap kepuasan konsumen pada Apotek K24 Bambu Apus Jakarta Timur adalah sebagai berikut:

1. Pada pengujian koefisien korelasi pearson product moment diperoleh hasil sebesar 0,183 berada pada interval 0,000-0,1999 yang menunjukkan bahwa terdapat hubungan yang sangat lemah antara pelayanan prima (variabel X) terhadap kepuasan konsumen (variabel Y) pada Apotek K24 Bambu Apus Jakarta Timur.

2. Dengan analisis koefisien determinasi diperoleh persentase besarnya pengaruh pelayanan prima terhadap kepuasan konsumen. Melalui perhitungan koefisien determinasi di peroleh besarnya persentase pengaruh pelayanan prima terhadap kepuasan konsumen sebesar 3,4\% dan sisanya adalah 96,6\% dipengaruhi oleh variabel-variabel lain seperti faktor kualitas pelayanan, harga, lokasi, dll.

3. Dan hasil pada persamaan regresi yaitu $\mathrm{Y}=27,072+0,168 \mathrm{X}$ menunjukkan bahwa, jika tidak ada pelayanan prima, maka kepuasan konsumen adalah 27,072 dan setiap penambahan (karena positif) pelayanan prima sebesar $1 \%$ maka akan meningkatkan kepuasan konsumen sebesar 0,168 .

4. Setelah diadakan pengambilan keputusan hipotesis ternyata dapat dilihat $\mathrm{t}$ hitung $>\mathrm{t}$ tabel $=$ $1,750>1,662$, berarti $\mathrm{H}_{\mathrm{o}}$ ditolak dan $\mathrm{H}_{\mathrm{a}}$ diterima, maka pelayanan prima mempunyai pengaruh terhadap kepuasan konsumen pada Apotek K24 Bambu Apus Jakarta Timur.

\section{Saran}

Berdasarkan kesimpulan-kesimpulan atas hasil penelitian, beberapa saran yang diharapkan dapat menjadi masukan bagi pihak Apotek K24 Bambu Apus Jakarta Timur yaitu sebagai berikut: 


\section{JURNAL PETIR}

Vol. 11, No. 2, September 2018, P-ISSN 1978-9262, E-ISSN 2655-5018

1. Secara keseluruhan pelayanan prima di Apotek K24 Bambu Apus Jakarta Timur baik tetapi ada dimensi pelayanan prima yang harus lebih diperhatikan dan ditingkatkan lagi pelayanannya seperti keramahan sikap terhadap konsumen agar konsumen dapat merasa puas atas pelayanan yang diberikan oleh perusahaan.

2. Sebaiknya Apotek K24 Bambu Apus Jakarta Timur melakukan survei secara rutin sebagai timbal balik atas pelayanan yang di berikan kepada konsumen baik berupa wawancara yang dilakukan kepada konsumen atas kepuasan yang dirasakan, melalui kotak saran atas keluhan atau kritik yang menjadi bahan masukan untuk Apotek K24 Bambu Apus Jakarta Timur agar dapat mewujudkan apa yang diinginkan dan dibutuhkan konsumen sehingga konsumen bisa merasa puas.

3. Seharusnya Apotek K24 Bambu Apus Jakarta Timur menambah pramuniaga pada saat pelayanan agar tidak terjadi antrian yang terlalu panjang dan konsumen tidak terlalu lama menunggu.

\section{DAFTAR PUSTAKA}

Arifin, J. (2017). SPSS 24 Untuk Penelitian dan Skripsi. Jakarta: PT. Elex Media Komputindo.

Daryanto, \& Setyobudi, I. (2014). Konsumen dan Pelayanan Prima. Yogyakarta: Gava Media.

Hasan, M. I. (2016). Pokok-Pokok Materi Statistik 2 (Statistik Inferensif). Jakarta: PT. Bumi Aksara.

Prasetyo, B., \& Jannah, L. M. (2012). Metode Penelitian Kuantitatif Teori dan Praktik. Jakarta: Rajawali Pers.

Rahmayanty, N. (2013). Manajemen Pelayanan Prima. Yogyakarta: Graha Ilmu.

Rangkuti, F. (2017). Customer Care Excellence. Jakarta: PT. Gramedia Pustaka Utama.

Riadi, E. (2016). Statistika Penelitian (Analisis Manual dan IBM SPSS). Yogyakarta: ANDI.

Setiawan, B. (2015). Teknik Praktis Analisis Data Penelitian Sosial dan Bisnis dengan SPSS. Yogyakarta: ANDI.

Siregar, S. (2015). Statistik Parametrik Untuk Penelitian Kuantitatif Dilengkapi dengan Perhitungan Manual dan Aplikasi SPSS Versi 17. Jakarta: PT. Bumi Aksara.

Sujarweni, V. W. (2015). Statistik Untuk Bisnis dan Ekonomi. Yogyakarta: Pustaka Baru Press.

Sunyoto, D. (2014). Konsep Dasar Riset Pemasaran dan Perilaku Konsumen. Yogyakarta: CAPS (Center for Academic Publishing Service).

Windasuri, H., \& Susanti, H. (2017). Excellent Service The Secrets of Building a Service Organization. Jakarta: PT. Gramedia Pustaka Media.

Yuniarti, V. S. (2015). Perilaku Konsumen Teori dan Praktik. Bandung: CV Pustaka Setia. 